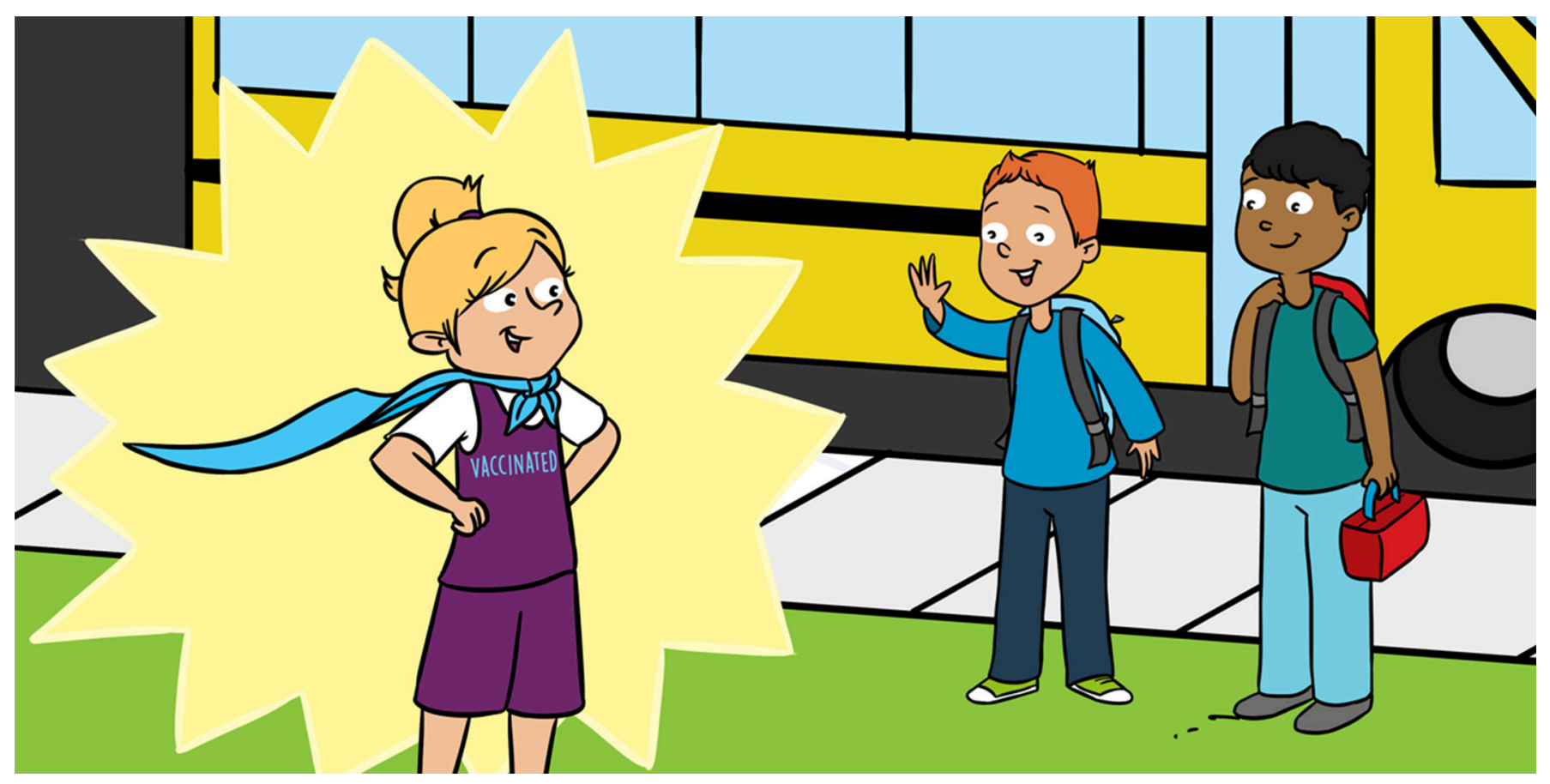

\title{
FLU FIGHTERS: HOW CHILDREN WHO GET THE NASAL INFLUENZA VACCINE PROTECT OTHERS
} FROM FLU

\author{
Alice Halliday ${ }^{1 *}$, Mica Roan Tolosa-Wright ${ }^{2}$, Aime Afua Boakye ${ }^{2}$ and John S. Tregoning ${ }^{3}$ \\ ${ }^{1}$ Cellular and Molecular Medicine, University of Bristol, Bristol, United Kingdom \\ ${ }^{2}$ National Heart and Lung Institute, Imperial College London, London, United Kingdom \\ ${ }^{3}$ Department of Medicine, Imperial College London, London, United Kingdom
}

YOUNG REVIEWER:

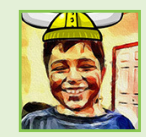

SANTIAGO

AGE: 10
Vaccines are a safe and effective way to protect people from infections. Vaccines train a system in your body -the immune systemto recognize the microbes that cause disease, so that the body can respond quickly when you encounter the real thing. There are many different types of vaccines available, and some include live microbes that have been weakened so that they cannot cause disease. In this article we focus on a nasal influenza vaccine that is given to children to prevent flu. Flu is a lung infection caused by the influenza virus. This vaccine is given as a nasal spray, and it trains the immune system to protect you in the place that matters-the nose. As well as protecting children who get vaccinated, this vaccine can reduce the likelihood of infection in others. Learn why kids who get the nasal spray flu vaccine are flu fighters! 


\section{PATHOGENS}

Microbes that can cause disease.

\section{INFLUENZA VIRUS}

The virus that causes influenza (flu).

\section{IMMUNE SYSTEM}

The cells and tissues in the body that help it to protect itself against infections.

\section{ANTIGENS}

The parts of a pathogen or vaccine that are seen by the immune system.

\section{VACCINES PROTECT US FROM INFECTIOUS DISEASES}

There are many types of microbes (such as viruses and bacteria), but only a few of these cause diseases. Disease-causing microbes are called pathogens and when pathogens invade the body they can make you sick. We are studying flu, a disease caused by the influenza virus, which affects the respiratory system (the lungs). Flu is different from "stomach flu," which is a common term for diarrhea and vomiting. Catching flu makes you feel terrible-normal symptoms include a high temperature (called a fever), muscle weakness, and tiredness. However, some people can get very, very sick, ending up in hospital or even dying. Flu is particularly dangerous for the very young ( $<1$ year old) and the elderly (more than 70 years old).

\section{THE FLU VIRUS: ALWAYS CHANGING}

Flu is a very common, global disease. Each year there is a period of time (a flu season), during which most of the flu cases happen, usually during the winter, but this can vary depending on where you live. For example, in the tropics, the flu season tends to reach its highest point in the rainy season. Influenza viruses also change (or mutate) from 1 year to the next, so that your immune system does not recognize them anymore, and is less able to protect you against infection and disease. This means that, every year, scientists need to check which flu viruses are infecting people and design new vaccines to protect against these current virus strains [1]. Each year, flu vaccines are usually made up of a mixture 3 or 4 strains that match the main circulating strains.

Sometimes, new strains of virus emerge that are completely different from the circulating virus strains. Scientists are really worried about the threat the new influenza viruses could pose to human health. Some new flu virus strains could affect more people than seasonal flu and cause a global outbreak. We call such strains pandemic strains. One hundred years ago, in 1918, there was a flu pandemic (often called the Spanish flu) that killed millions of people worldwide-even more people than both world wars added together.

The immune system is a system of the body that helps to protect the body against pathogens. One way to prevent flu infections is to use vaccines to train the immune system to recognize specific parts of the virus, called antigens, without making you sick. After being vaccinated, your immune system remembers what the flu virus looks like and can quickly recognize and eliminate the real virus if you encounter it in the future. 
Figure 1

How lymphocytes protect against flu. There are two main types of lymphocyte: B cells and $T$ cells. They act in different ways to help protect you against an infection with a flu virus. $B$ cells produce antibodies, which are specific to a surface antigen on the influenza virus. Antibodies can block the virus from infecting other cells. T cells can recognize antigens from the flu virus on infected cells, and then kill the infected cells to prevent the virus from spreading to new cells.

\section{LYMPHOCYTE}

A type of immune cell. Each lymphocyte is specific to one antigen. The two main types of lymphocytes are B cells, which produce antibodies, and T cells, which kill infected cells.

\section{ANTIBODIES}

Molecules made by $\mathrm{B}$ cells that stick to antigens on a pathogen

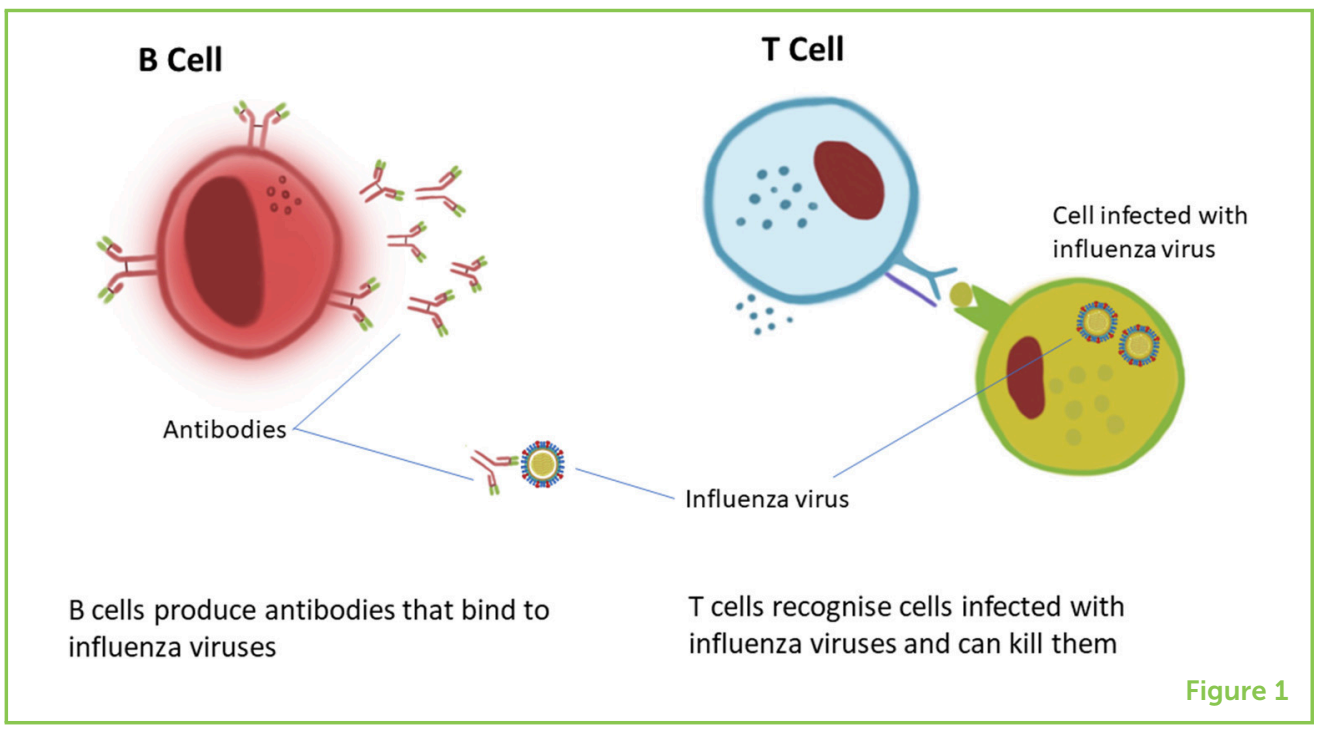

\section{THE IMPORTANT ROLE OF THE IMMUNE SYSTEM}

To protect us from flu infection, special cells of the immune system, which are called lymphocytes, need to be able to recognize the influenza virus. They do this by recognizing specific antigens from the influenza virus. In our bodies, we have a whole library of lymphocytes and each one is specific for a different antigen. So, for example, your body has influenza-specific lymphocytes, and after they "see" influenza antigen they multiply and help the body fight the influenza virus. We can group the lymphocytes by the way in which they prevent infections: B lymphocytes (B cells) produce antibodies (molecules that stick to the virus), and T lymphocytes ( $T$ cells) kill virus-infected cells [2] (Figure 1).

However, the process of activating lymphocytes can take several days, and in that time the flu virus can do a lot of damage. To avoid this delay in response each time we are infected by a virus, the immune system has a clever process of remembering viruses it has seen before, so that it can act more quickly the next time. This response is called immune memory [2].

\section{VACCINES TRAIN THE IMMUNE SYSTEM}

Flu vaccines are like a training session for your immune system. They contain antigens from influenza and they train immune memory without the body being exposed to the real virus. If the body encounters influenza virus after vaccination, the antigen-specific memory cells will be ready to respond quickly. So, with vaccines, we get immune memory without the pathogen causing any damage-a safe and effective way to protect against disease. 
LIVE ATTENUATED

INFLUENZA

VACCINE (LAIV)

A type of influenza vaccine given as a nasal spray. This vaccine contains live, weakened influenza viruses.

\section{ATTENUATED}

Weakened.

\section{Table 1}

Differences between LAIV and other flu vaccines.
Currently, there are many different vaccines available to help protect people against flu. One type, called the live attenuated influenza vaccine (LAIV) is now offered to school children in many countries worldwide. In this article we will explain how this vaccine is different from other flu vaccines, and how it can even protect unvaccinated people from getting sick.

\section{WHAT IS A LIVE ATTENUATED VACCINE?}

There are many different types of flu vaccines. Some contain a killed preparation of the whole virus, while others contain just one or a few pieces (antigens). Other vaccines contain live pathogens that have been weakened (or attenuated), so that they do not cause disease: these are called live attenuated vaccines. The good thing about live vaccines is that they usually work much better than other vaccines. This is because a living microbe is able to reproduce in the body, leading to more activated immune cells and stronger immune memory.

\section{ARE LIVE VACCINES SAFE?}

You might be wondering why live microbes are given to people in vaccines-is this safe? It is a good question! Luckily, live attenuated vaccines do not cause disease in most people, because they have been scientifically weakened to be safe. In the case of LAIV, the flu viruses have been modified so that they can only grow at cooler temperatures. This means that they are able to grow in your nose, which is cooler than the rest of your body because you are breathing in air $\left(\sim 30^{\circ} \mathrm{C}\right)$, but not in your lungs, which are at the same temperature as the rest of your body $\left(37^{\circ} \mathrm{C}\right)$. The warmer temperatures in the lung kill the virus in the vaccine by cooking it. But the vaccine can replicate for a short period in the nose, enough to start an immune response that is similar to a natural infection with the real flu virus. The main differences between LAIV and other flu vaccines are described in Table 1.

\begin{tabular}{lll} 
& LAIV & Other flu vaccines \\
How is it given? & Spray & Injection \\
Where is it given? & Up the nose & Into the arm \\
Antigen/s & Live attenuated viruses & Killed viruses \\
Does it hurt & No & Sometimes \\
Known side effects & Runny nose & Pain at injection site \\
& Headache & Muscle aching \\
& Muscle aching (rare) & Fever (rare) \\
& Vomiting (very rare) & Feeling unwell (very rare) \\
Which age group/s is it given to? & Children only & All ages from 6 months \\
\hline
\end{tabular}


So, why should you get vaccinated with LAIV? We think there are several benefits:

\section{It Does Not Hurt}

Most vaccines currently available for flu are given by injection into the arm. The LAIV is different-it is given as a nasal spray, not an injection. Many people think this is much better, because it does not hurt! However, some people who receive LAIV do report some side effects, including a runny or blocked nose, a headache, muscle aches and a cough [3]. These side effects are rare and usually mild and do not last long.

\section{A Nasal Spray-Gets the Vaccine to the Right Place}

Flu is a disease of the respiratory system, meaning it mostly infects the nose, throat, and lungs. Therefore, for your immune system to have the best chance of fighting off a new infection quickly, the flu-specific immune cells will work best if they are in the respiratory system, too. That is why we give LAIV as a nasal spray-so that the vaccine reaches the part of the body that needs to be protected from the flu virus [4].

\section{Good for Granny}

Interestingly, it is not just the vaccinated children who are protected against infections. Unvaccinated children are really good at spreading viruses around, because they wash their hands less and tend to mix with more people regularly. Vaccinating children stops them from spreading the virus to other people, including babies and older family members who can get much sicker if they get the flu (Figure 2). This protection of people who are not vaccinated is called herd immunity.

\section{LAIV Gives a Different Kind of Protection}

The injectable flu vaccines are good at creating antibody responses, but not $T$ cell responses. Because LAIV can stimulate strong $T$ cell responses AND strong antibody responses, it is believed that LAIV can help the immune system to protect you from infections, even infections with strains of flu that were not included in the vaccine [4]. It would be helpful if LAIV can protect against new strains, because at any time a new flu virus could come along that causes more severe disease.

\section{FUTURE SCIENTIFIC QUESTIONS}

We are still not sure if LAIV can protect against flu strains other than the circulating ones, which is why more work on how LAIV protects children from flu is needed. By researching how LAIV works and figuring out how it is able to stimulate the immune system, we may be 


\section{Figure 2}

How children vaccinated with LAIV protect others from flu. (A) Children who do not receive the flu vaccination (in orange) can get sick if they are in contact with someone who has the flu virus. They can also spread the virus to others, including family members who might be more likely to get very sick, such as older people. (B) However, children who receive LAIV (in green) are better protected against catching the flu virus. As well as preventing the children from getting sick, vaccination also protects others around them, because the children would not spread the virus to others. (C) So, getting the LAIV vaccine is good for Granny, since she will be less likely to get the flu.
A

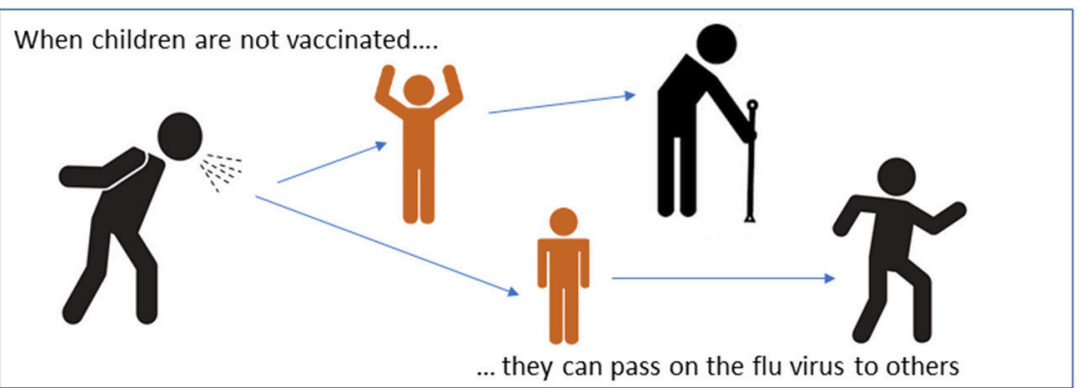

B

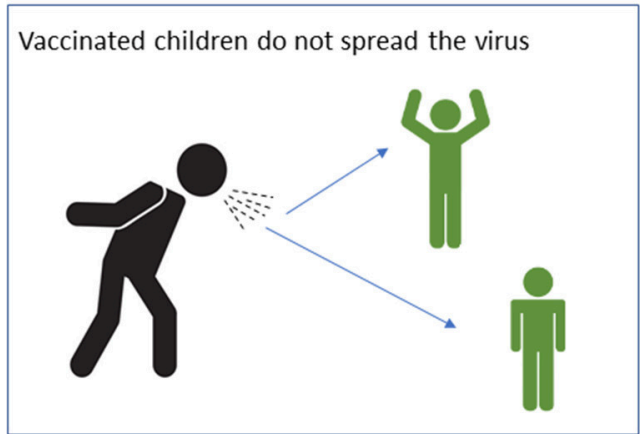

C

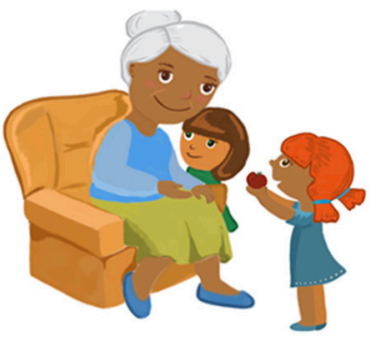

Figure 2

able to develop an even better vaccine, which could protect us against new pandemic strains of flu virus.

\section{THANKS, FLU FIGHTERS!}

So, finally, if you have been given LAIV this flu season, here is a big THANK YOU! You have done your part in protecting everyone against flu.

\section{REFERENCES}

1. Tregoning, J. 2017. Flu, flu vaccines, and why we need to do better. Front. Young Minds 5:7. doi: 10.3389/frym.2017.00007

2. Lundy, S. K. 2018. The immune system, in sickness $\&$ in health-part 1: microbes and vaccines. Front. Young Minds 6:49. doi: 10.3389/frym.2018.00049

3. Center for Disease Control. 2018. Possible Side-Effects from Vaccines. Available online at: https://www.cdc.gov/vaccines/vac-gen/side-effects.htm\#flu

4. Sridhar S., Brokstad K. A., and Cox R. J. 2015. Influenza vaccination strategies: comparing inactivated and live attenuated influenza vaccines. Vaccines (Basel). 3:373-89. doi: 10.3390/vaccines3020373

SUBMITTED: 23 November 2018; ACCEPTED: 30 April 2019; PUBLISHED ONLINE: 21 May 2019.

EDITED BY: Viduranga Y. Waisundara, Australian College of Business and Technology-Kandy Campus, Sri Lanka 


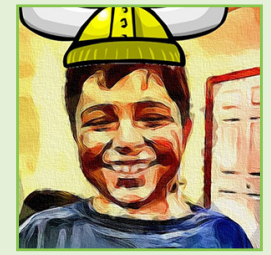

CITATION: Halliday A, Tolosa-Wright MR, Boakye AA and Tregoning JS (2019) Flu Fighters: How Children Who Get the Nasal Influenza Vaccine Protect Others From Flu. Front. Young Minds 7:69. doi: 10.3389/frym.2019.00069

CONFLICT OF INTEREST STATEMENT: The authors declare that the research was conducted in the absence of any commercial or financial relationships that could be construed as a potential conflict of interest.

COPYRIGHT (c) 2019 Halliday, Tolosa-Wright, Boakye and Tregoning. This is an open-access article distributed under the terms of the Creative Commons Attribution License (CC BY). The use, distribution or reproduction in other forums is permitted, provided the original author(s) and the copyright owner(s) are credited and that the original publication in this journal is cited, in accordance with accepted academic practice. No use, distribution or reproduction is permitted which does not comply with these terms.

\section{YOUNG REVIEWER}

\section{SANTIAGO, AGE: 10}

Hello my name is Santiago, and I am 10 years old (almost 11). You can call me Santi. My favorite sport is soccer. I play for a team and my position is midfield. I like to play with my friends. I am in fifth grade. I like History and Science, especially chemistry or lab experiments.

\section{AUTHORS}
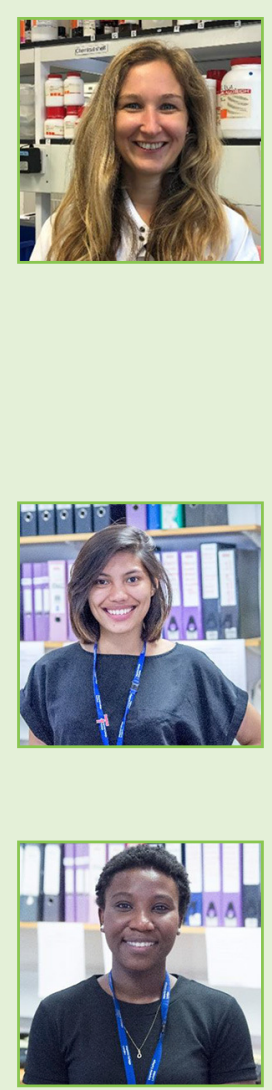

\section{ALICE HALLIDAY}

I am an early career researcher at the University of Bristol with an interest in infectious diseases - particularly those in disadvantaged areas of the world. I am fascinated by the ongoing battles that take place between the microbes that can cause disease and our immune cells, which are designed to fight them. I currently work on group A streptococcus, a bacterium that causes a range of different diseases. However, I have an interest in many different other infections and in the development of improved vaccines. I also enjoy talking about science with children and the wider community. *alice.halliday@bristol.ac.uk

\section{MICA ROAN TOLOSA-WRIGHT}

I studied Forensic Science (B.Sc.Hons.) and have since moved to using the skills I gained to understand the perpetrators of disease, rather than perpetrators of crime. I am currently a Genomic Medicine Master's student as well as a research technician in Prof. Ajit Lalvani's laboratory. I am currently investigating the immune response to tuberculosis infection, and influenza vaccines.

\section{AIME AFUA BOAKYE}

I am a Junior Study Coordinator and the Patient and Public Involvement (PPI) and Public Engagement (PE) Lead within the Health Protection Research Unit in Respiratory Infections at Imperial College London. I support a range of clinical studies in the areas of tuberculosis, flu and pneumonia, liaising between Imperial 


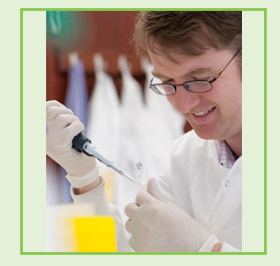

College London and Public Health England. I have a long-standing interest in clinical research with the aim of making a difference in the lives of patients and those around them. I gained my undergraduate degree in Biomedical Science (B.Sc.) at the University of Warwick and an M.Sc. in Immunology from Imperial College London.

\section{JOHN S. TREGONING}

I work at Imperial College London, in the UK. I find a broad range of biological sciences fascinating-especially anything to do with infection: how microbes make us sick, how the body gets us well again, and how we can stop the microbes and help the body. I spend most of my time researching and teaching about viral infections in the lungs. In addition to developing new vaccines for influenza (flu) and respiratory syncytial virus (RSV), I am investigating how the immune system protects us against these infections. 